\title{
Biodegradation of Naphthalene using Pseudomonas putida and Bacillus subtilis Immobilized on Snail Shell
}

\author{
*AINA, OE; AGBAJI, EB; NWOKEM, NC \\ Department of Chemistry, Ahmadu Bello University, Zaria, Nigeria. \\ *Corresponding author address: oluwatoyinaina24@gmail.com, Phone: +2348060969454 \\ Co-authors addresses: bola.agbaji@gmail.com,nsidibe19@gmail.com
}

\begin{abstract}
This study investigated snail shell as a carrier to immobilize Pseudomonas putida and Bacillus subtilis isolated from refinery effluent for the degradation of naphthalene in synthetic wastewater at various process conditions such as initial naphthalene concentration, $\mathrm{pH}$, adsorbent dosage and ambient temperature of $30{ }^{\circ} \mathrm{C}$ in batch mode. The results showed that the adsorption and the biodegradation capacity increased with increase in naphthalene concentration, where $73.11 \%, 74.46 \%$ and $65.20 \%$ of the optimum concentration $(50 \mathrm{mg} / \mathrm{L})$ were removed by immobilized Pseudomonas putida, Bacillus subtilis, and snail shell respectively after 72 hours incubation. The optimal degradation occurred at the adsorbent dosage of $2 \mathrm{~g}$ at $\mathrm{pH} 9$ and $\mathrm{pH} 7$ for the adsorption and biodegradation respectively. The results were well fitted to both Langmuir and Freundlich models. Therefore, snail shell can be employed as a low-cost adsorbent and solid support matrix for immobilizing microorganisms in remediating hydrocarbon contaminants.
\end{abstract}

\section{DOI: https://dx.doi.org/10.4314/jasem.v22i7.12}

Copyright: Copyright (c) 2018 Aina et al. This is an open access article distributed under the Creative Commons Attribution License (CCL), which permits unrestricted use, distribution, and reproduction in any medium, provided the original work is properly cited.

Dates: Received: 19 May 2018; Revised: 27 June: 2018; Accepted: 12 July 2018

Keywords: Biodegradation; Naphthalene; Immobilization; Snail shell.

Petroleum hydrocarbons and their derivatives are the main the energy source for various industrial, automotive and domestic uses. But the deliberate use of these products has been a cause for concern, due to the oil spills as a result of exploration and exploitation (Onyegeme-Okerental et al., 2017). This problem of oil spillage has been a global problem that has occurred since the discovery of crude oil (Kadafa, 2012). Most of the components of petroleum hydrocarbons are toxic, carcinogenic and mutagenic in nature (Das and Chandra, 2011). According to reports by international environmental groups, the Niger Delta in Nigeria has been listed as one of the five most severely oil-damaged ecosystems in the world (Kadafa, 2012). Also, Vidal (2010) reported that due to the anthropogenic activities occurring within this region, their waters are polluted resulting in varying degrees of health problems. Therefore, the effective removal of crude oil and their products is a problem of paramount concern to the world at large.

Several methods have been employed for the remediation of petroleum hydrocarbon, they include physical, chemical and biological techniques (Yadav and Hassanizadeh, 2011). However, these physicochemical methods are acquainted with problems such as incomplete decomposition or breakdown of contaminants, and moreover, the technologies are comparatively expensive when compared to biodegradation (Das and Chandra, 2011Benchiuk and Chibani, 2017). Although, freely suspended cells used in biodegradation have limited capacity, recently the new trend which has gained more attention is cell immobilization on solid support or adsorbent (Sreenivasulu, 2012), and many of these technologies have been used successfully for crude oil bioremediation. Adsorbents such as activated carbon, kaolin, orange peel, groundnut shell, sugarcane bagasse, natural polymeric matrices (agar, alginate, carrageenan, chitosan) and also synthetic matrices such as polyvinyl alcohol (PVA) and polyurethane have been used extensively for hydrocarbons remediation (Agarry and Aremu, 2012; Partovinia and Naeimpoor, 2013). However, snail shell with the incorporation of microorganisms has rarely been used to remediate oil pollutants. Therefore, this study investigated the potential of snail shell for immobilizing Pseudomonas putida and Bacillus subtilis to remove naphthalene.

\section{MATERIALS AND METHODS}

Collection of samples and Reagents: All reagents used were of analytical grade purchased from Sigma Aldrich Chemicals, USA. The refinery effluent used for the isolation was collected from Kaduna Refinery and Petrochemical Company (KRPC) effluent ponds. 
The sample was then transported at ambient temperature to the Department of Microbiology, Ahmadu Bello University, Zaria for the isolation. The snail shell was obtained from a dumpsite located within National Research Institute of Chemical Technology (NARICT) staff quarters, Basawa, Zaria and identified as African giant snail shell (Achatina achatina) at the Department of Biological Sciences, Ahmadu Bello University, Zaria.

Sample Preparation and Characterization: The snail shells were washed thoroughly with detergent and rinsed with tap water and distilled water, to ensure complete removal of all adhering impurities. The washed snail shells were then sun-dried for 48 hours, pulverized using a laboratory mill (Thomas Wiley model 4, USA) and then oven dried at $100{ }^{\circ} \mathrm{C}$ for 12 hours. The dried powdered sample were screened with a sieve of particle size $0.125 \mathrm{~mm}$ and finally subjected for characterization using an X-ray Fluorescence spectroscopy (X-Supreme 8000, UK).

Preparation of Reagents: A $0.1 \mathrm{~g} / \mathrm{L}$ naphthalene stock solution was prepared by dissolving the compound in acetone-water $30: 70 \% \mathrm{v} / \mathrm{v}$, standard concentrations ranging from $10-50 \mathrm{mg} / \mathrm{L}$ were then prepared by serial dilutions of the stock solution in distilled water.

Microorganisms' strains and inoculum preparation for biodegradation: The relevant microorganism strains were isolated using the method described by Naga et al., (2016) with a slight modification. The isolates were identified with a combination of microscopic and biochemical techniques using microgen kits, which identified the most likely species as Pseudomonas putida and Bacillus subtilis with $90.50 \%$ and $99.68 \%$ similarity. The strains were stored on a nutrient agar slant medium at $4{ }^{\circ} \mathrm{C}$ for further studies. Primary and secondary cultures were prepared respectively as described by Agarry and Aremu (2012). The secondary culture was then used as the inoculum for the degradation studies as this ensures full acclimatization of the organisms to grow on the naphthalene as the sole source of carbon and energy.

Batch Experiment: The degradation study was carried out by adding $100 \mathrm{~cm}^{3}$ each of the prepared inoculums of the Pseudomonas putida and Bacillus subtilis separately into different glass bottles containing a known amount of snail shell $(2-5 \mathrm{~g})$. Exactly $150 \mathrm{~cm}^{3}$ of synthetic wastewater $\left(\mathrm{K}_{2} \mathrm{HPO}_{4}, 1.0 \mathrm{~g} ; \mathrm{KH}_{2} \mathrm{PO}_{4}, 0.5\right.$ g; $\left(\mathrm{NH}_{4}\right)_{2} \mathrm{SO}_{4}, 0.5 \mathrm{~g} ; \mathrm{NaCl}, 0.5 \mathrm{~g} ; \mathrm{CaCl}_{2}, 0.02 \mathrm{~g}$, $\mathrm{MnSO}_{4}, 0.02 \mathrm{~g}$ and Molybdenum powder, 0.02 in $1000 \mathrm{~cm}^{3}$ of deionized water) with known amount of naphthalene concentration $(10-50 \mathrm{mg} / \mathrm{L})$ was added to the respective glass bottles, the wastewater was maintained at a known $\mathrm{pH}(5-9)$. The glass bottles were placed in a rotary shaker for 72 hours at a speed of $180 \mathrm{rpm}$ and temperature of $30{ }^{\circ} \mathrm{C}$ so as to reach equilibrium. A similar process was repeated for the control (Agarry and Aremu, 2012). The naphthalene concentrations were determined using a UV-VIS spectrophotometer (Agilent Cary 300, USA).

The percentage naphthalene removal was also calculated using equation 1 ;

$$
\text { Removal efficiency (\%) }=\frac{\mathrm{C}_{\mathrm{o}}-\mathrm{C}_{\mathrm{e}}}{\mathrm{C}_{\mathrm{o}}} * 100
$$

The amount of the naphthalene adsorbed, $\mathrm{q}_{\mathrm{e}}$, was also calculated from equation 2 ;

$$
\mathrm{q}_{\mathrm{e}}=\frac{\mathrm{V}\left(\mathrm{C}_{\mathrm{o}}-\mathrm{C}_{\mathrm{e}}\right)}{\mathrm{m}}
$$

Where, qe is the amount of adsorbate naphthalene adsorbed in milligram per gram of the adsorbent; $\mathrm{C}_{\mathrm{o}}$ is the initial concentration of the naphthalene before adsorption process; $\mathrm{C}_{\mathrm{e}}$ is the equilibrium concentration of the naphthalene in the aqueous medium after adsorption process; $m$ is the mass in gram of the adsorbent; $\mathrm{V}$ is the volume of the solution in Litre.

\section{RESULTS AND DISCUSSION}

The X-ray fluorescence (XRF) analysis of the snail shell for the major and minor components are given in Table 1. The snail shell was substantial with $\mathrm{CaO}$, this showed calcium as the major element making up to $96.13 \%$. This major element present in the shell aids microorganism in producing enzymes needed for the breakdown of contaminants, although, excess nutrient contents can also inhibit biodegradation of hydrocarbons (Chaineau et al., 2005); in this study, moderate elemental values were obtained except for calcium. Therefore, the composition of the snail shell makes it a potential adsorbent material for contaminant adsorption.

\begin{tabular}{ll} 
Table 1: Chemical Composition of the Snail Shell \\
\multicolumn{2}{l}{ Component }
\end{tabular}


Figure 1 is an illustration of the effect of $\mathrm{pH}$ on the adsorption and biodegradation of naphthalene at constant naphthalene concentration of $50 \mathrm{mg} / \mathrm{L}$ and optimum dosage value $(2 \mathrm{~g})$. The optimum removal rate occurred at $\mathrm{pH} 9$ for the adsorption of naphthalene. It was clear that the adsorption of naphthalene varies with $\mathrm{pH}$, that is, as the $\mathrm{pH}$ increased from $5-9$, there was a corresponding increase in the percentage removal. However, it was a contrasting observation for the biodegradation of naphthalene with Pseudomonas putida and Bacillus subtilis incorporated on the snail shell with the optimum removal achieved at $\mathrm{pH}$ 7. This shows that the bacteria were more active at a neutral $\mathrm{pH}$. This observation is in agreement with the literatures, that microorganisms achieve better efficiency at $\mathrm{pH} 6-8$, with the optimum obtainable at $\mathrm{pH} 7$ (Agarry and Aremu, 2012; Darsa et al., 2014;).

Figure 2 shows the percentage of naphthalene adsorbed and biodegraded at varying adsorbent doses set at 2, 3 and $5 \mathrm{~g}$ respectively with a fixed naphthalene concentration of $50 \mathrm{mg} / \mathrm{L}$ and a $\mathrm{pH}$ of 7 . It was found that the percentage naphthalene removal of both adsorption and biodegradation decreases with increasing amounts for adsorbent from $2 \mathrm{~g}$ to $5 \mathrm{~g}$. An initial increase in adsorption capacity was observed with an increase in the adsorbent dose, since the number of particles increased and, therefore, more surface was available for hydrocarbon binding. But a further increase in the adsorbent dosage beyond the maximum adsorption capacity, however, resulted in a decrease in capacity as shown in Figure 2. This capacity reduction could be due to the overlap of adsorption as a result of overcrowding of adsorbent particles beyond the optimal dose (Oladunni et al., 2012). However, for the biodegradation, a high substrate content may inhibit the activity of microorganisms (Lin et al., 2015), as excess nutrient aid microbial growth but does not necessarily improve the rate of biodegradation (Chaineau et al., 2005). Thus, the results show that the adsorbent dose of $2 \mathrm{~g}$ has the highest removal efficiency for this study.

Figure 3 shows the effect of concentration on the adsorption and biodegradation of naphthalene. This was investigated over a concentration of $10-50 \mathrm{mg} / \mathrm{L}$ at constant $\mathrm{pH}$ and adsorbent dosage of 7 and $2 \mathrm{~g}$ respectively. The results obtained in both the adsorption and biodegradation study indicated that as the initial concentration increased, there was a corresponding increase in the percentage naphthalene removal. This could be attributed to the availability of active sites for naphthalene removal. However, as the concentration increases, the percent removal was higher in the biodegradation process across all the concentration range than the adsorption.

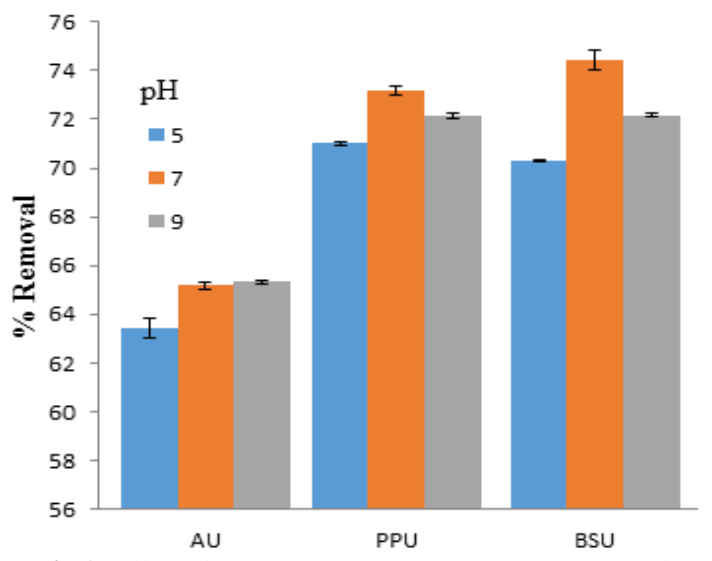

Fig 1: Effect of $\mathrm{pH}$ on the Adsorption/Biodegradation of Naphthalene: Key: AU = snail shell; PPU = Pseudomonas putida immobilized on snail shell; BSU = Bacillus subtilis immobilized on snail shell

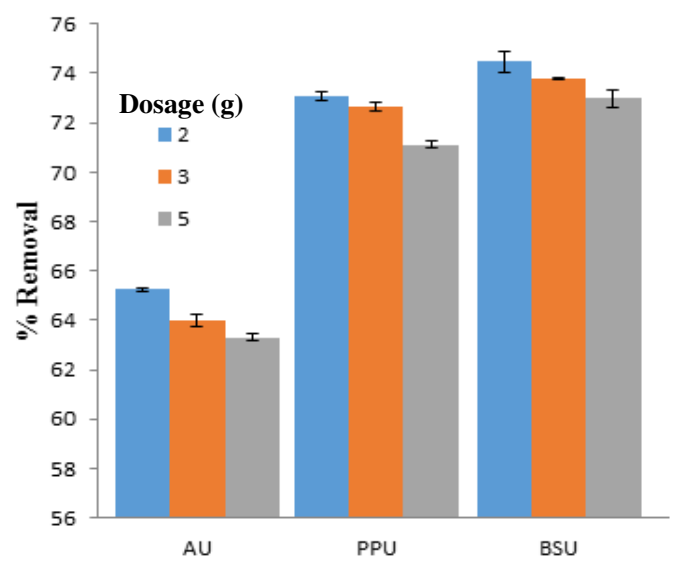

Figure 2: Effect of Dosage on the Adsorption/Biodegradation of Naphthalene

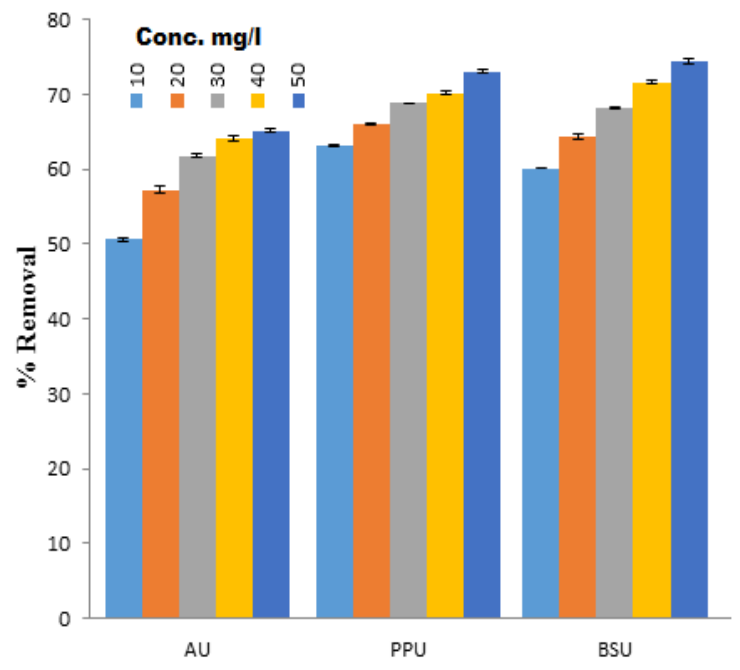

Fig 3: Effect of Initial Concentration on the Adsorption/Biodegradation of Naphthalene 
This showed that biodegradation predominates after adsorption has reached equilibrium, thus revealing the synergistic effect of simultaneous adsorptionbiodegradation on the removal of naphthalene from wastewater (Agarry and Aremu, 2012). Furthermore, the advantage could also be attributed to the fact that the mechanism works partly due to the fact that naphthalene can be adsorbed onto the snail shell and further degraded by the two immobilized bacteria (Lin et al., 2015).

Adsorption Isotherms: Langmuir model assumes that monolayer adsorption takes place on a surface containing a finite number of adsorption sites. It is defined in equation 1 :

$$
\mathrm{q}_{\mathrm{e}}=\frac{\mathrm{q}_{\text {max }} \mathrm{bC}_{\mathrm{e}}}{1+\mathrm{bC}_{\mathrm{e}}}
$$

The linearized Langmuir model equation is expressed as below:

$$
\frac{1}{\mathrm{q}_{\mathrm{e}}}=\frac{1}{\mathrm{q}_{\max }}+\frac{1}{\mathrm{bq}_{\max } \mathrm{C}_{\mathrm{e}}}
$$

Where, $\mathrm{q}_{\mathrm{e}}$ is the amount of adsorbate adsorbed per gram of dried adsorbent at equilibrium (mg adsorbate/g of dried adsorbent), $\mathrm{q}_{\max }$ is the maximum monolayer coverage capacity ( $\mathrm{mg} / \mathrm{g})$, b is Langmuir constant or adsorption coefficient or the adsorption affinity (L/mg) for binding of adsorbate on the adsorbent sites and $\mathrm{C}_{\mathrm{e}}$ is equilibrium (residual) adsorbate concentration in solution after adsorption (mg/L). The values of $q_{\max }$ and $b$ can be calculated from the intercept $\left(\frac{1}{q_{\max }}\right)$ and slope $\left(\frac{1}{q_{\max } b}\right)$ of the plot $\frac{1}{\mathrm{q}_{\mathrm{e}}}$ against $\frac{1}{\mathrm{C}_{\mathrm{e}}}$.

The essential characteristics of Langmuir model can be described by dimensionless separation factor, $\mathrm{R}_{\mathrm{L}}$, given as:

$$
\mathrm{R}_{\mathrm{L}}=\frac{1}{1+\mathrm{bC}_{\mathrm{o}}}
$$

Where $\mathrm{C}_{\mathrm{o}}$ is the highest initial solute concentration. $R_{L}$ Values indicate whether the adsorption is unfavourable $\left(R_{L}>1\right)$, linear $\left(R_{L}=1\right)$, favourable $(0<$ $\left.R_{L}<1\right)$, or irreversible $\left(R_{L}=0\right)$.

A linear adsorption isotherms were presented in Figure 4-6. The respective $q_{\max }$ and $b$ of linear expressions of Langmuir adsorption isotherm were calculated from the slopes and intercepts of the linear plots of 1/qe versus $1 / \mathrm{Ce}$. The values obtained for $\mathrm{q}_{\max }, \mathrm{b}, \mathrm{R}^{2}$ and $\mathrm{R}_{\mathrm{L}}$ were listed on Table 2 . It was observed that the linearized form of the Langmuir isotherm was linear over the concentration range studied and the result fitted well with the model with respect to $\mathrm{R}^{2}$ values obtained. The high degree of correlation for the linearized Langmuir relationship observed suggest monolayer adsorption on specific sites or single surface reaction.

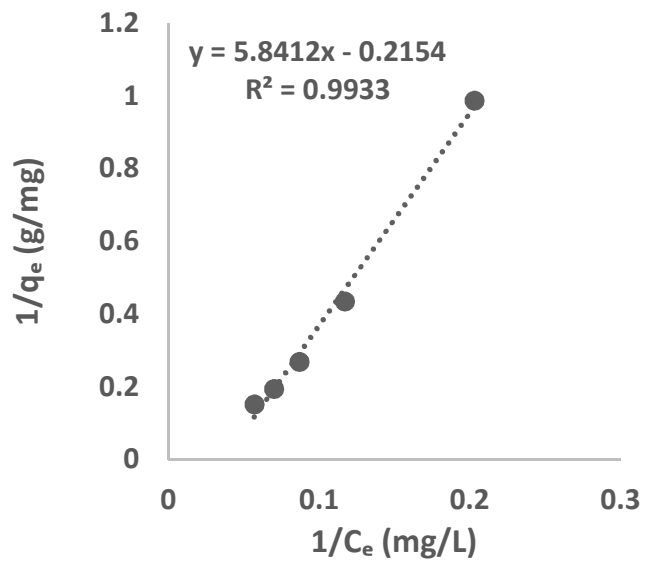

Fig 4: Langmuir Isotherm plot for naphthalene adsorption on snail shell

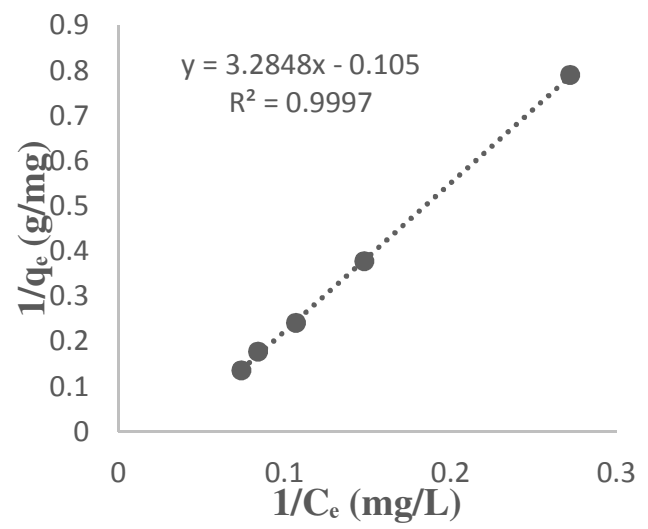

Fig 5: Langmuir Isotherm plot for naphthalene biodegradation with Pseudomonas putida immobilized on snail shell

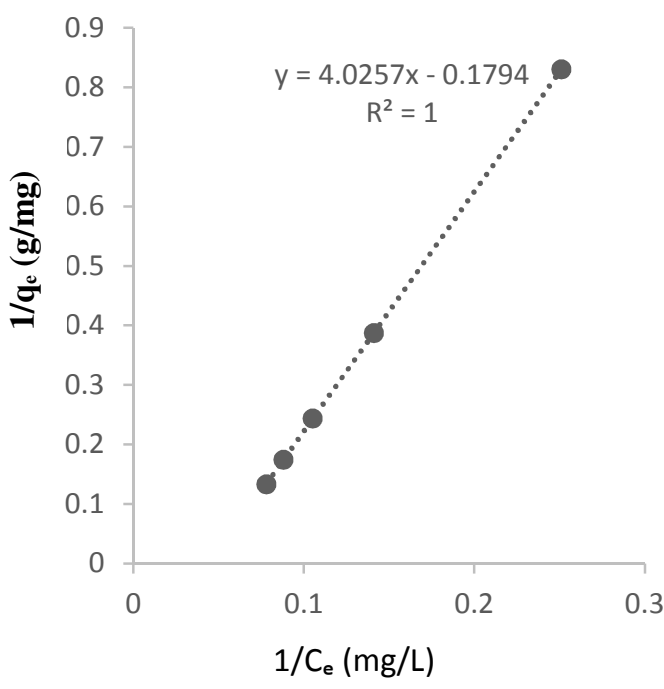

Fig 6: Langmuir Isotherm plot for naphthalene biodegradation with Bacillus subtilis immobilized on snail shell 
The Freundlich model, on the other hand, assumes adsorption on a heterogeneous surface. The empirical equation proposed by Freundlich is given by equation 4:

$$
\mathrm{q}_{\mathrm{e}}=\mathrm{K}_{\mathrm{f}} \mathrm{C}_{\mathrm{e}}^{1 / \mathrm{n}}
$$

The linearized Freundlich model equation is given as equation 7.0:

$$
\log q_{e}=\log K_{f}+\frac{1}{n} \log C_{e}
$$

Where $K_{f}$ is Freundlich Constant measuring adsorption capacity $(\mathrm{L} / \mathrm{mg})$, and $\mathrm{n}$ is constant related to adsorption efficiency and energy of adsorption or adsorption intensity of the adsorbent. Generally, $\mathrm{n}>1$ suggests favourable adsorption. It has also been used to evaluate whether the adsorption process is physical $(\mathrm{n}>1)$, chemical $(\mathrm{n}<1)$ or linear $(\mathrm{n}=1)$ (Oladunni et al., 2012). The slope and the intercept correspond to $\frac{1}{n}$ and $\mathrm{K}_{\mathrm{f}}$ respectively, which are obtained from the straight line plot of $\log q_{e}$ against $\log C_{e}$.

Figure 7-9 are the Freundlich isotherm plots of log qe against $\log \mathrm{Ce}$ which all gave straight lines. The slopes and the intercepts correspond to $\left(\frac{1}{n}\right)$ and $K_{f}$ respectively. The results are presented in Table 2 . The obtained $\mathrm{n}$ values are all below one, which is an indication of a cooperative adsorption in sites with different binding energies and indicative of favourable adsorption process (Abechi et al., 2013).

The correlation coefficient $\left(\mathrm{R}^{2}\right)$ values obtained from the adsorption and biodegradation studies showed that the isotherms also fitted well with the Freundlich model.

Conclusion: This study indicated the effectiveness of snail shell for the removal of naphthalene by adsorption and biodegradation from synthetic wastewater. The study was carried out under different conditions in batch and equilibrium modes. The snail shell exhibited competitive properties both for an enhanced adsorption process and bacteria biomass immobilization. The experimental data obtained from the study of both Langmuir and Freundlich Isotherm models could be used to describe the naphthalene sorption equilibrium as all the sorbent systems gave a better fit. The experimental conditions investigated showed that snail shell immobilized Pseudomonas putida and Bacillus subtilis (adsorptionbiodegradation) were very efficient due to the combination of two process. Thus, Pseudomonas putida and Bacillus subtilis immobilized on snail shell is a promising alternative to bioremediation of polluted sites.

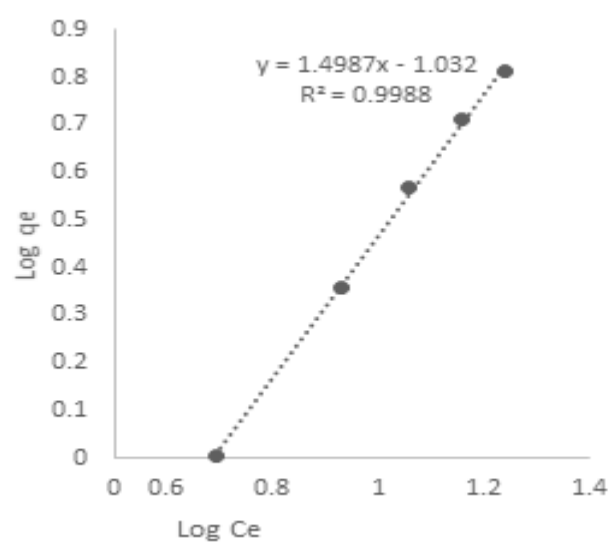

Fig 7: Freundlich Isotherm plot for naphthalene adsorption on snail shell

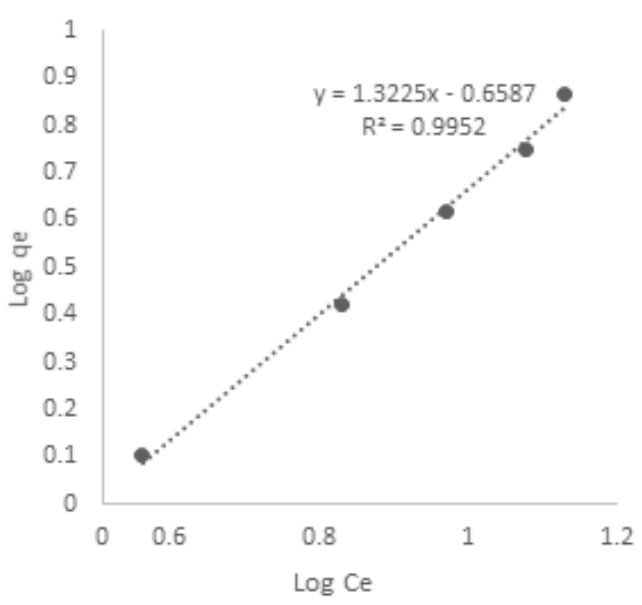

Fig 8: Freundlich Isotherm plot for naphthalene Biodegradation with Pseudomonas putida immobilized on snail shell

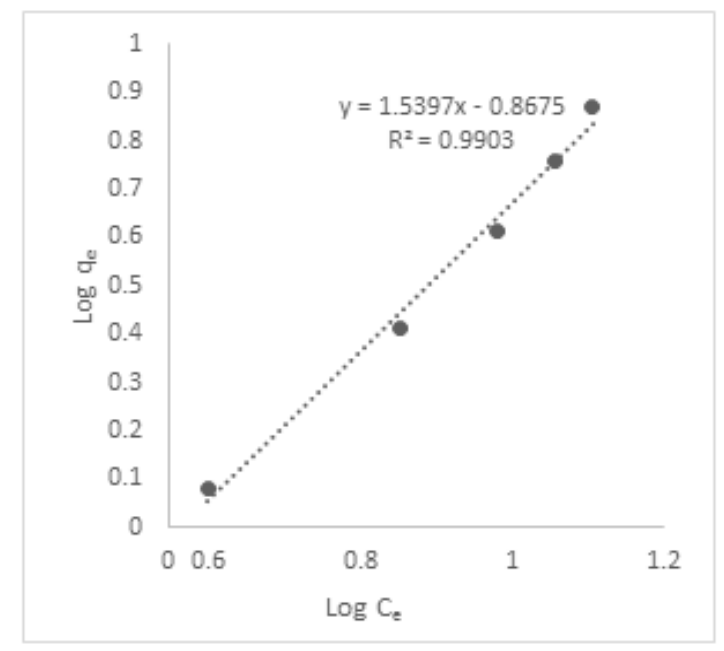

Fig 9: Freundlich Isotherm plot for naphthalene Biodegradation with Bacillus subtilis immobilized on snail shell 
Table 2: Correlation parameters of Langmuir and Freundlich Isotherms

\begin{tabular}{lcllllll}
\hline \multicolumn{3}{c}{ Langmuir } & \multicolumn{5}{c}{ Freundlich } \\
\hline $\begin{array}{l}\text { Treatment on } \\
\text { Hydrocarbon }\end{array}$ & $\begin{array}{c}\mathrm{q}_{\max } \\
(\mathrm{mg} / \mathrm{g})\end{array}$ & $\mathrm{b}(\mathrm{L} / \mathrm{mg})$ & $\mathrm{R}_{\mathrm{L}}$ & $\mathrm{R}^{2}$ & $\mathrm{n}$ & $\begin{array}{c}\mathrm{K}_{\mathrm{f}} \\
(\mathrm{L} / \mathrm{mg})\end{array}$ & $\mathrm{R}^{2}$ \\
\hline AU & -4.64 & -0.0369 & -1.1834 & 0.9933 & 0.67 & 0.09 & 0.9988 \\
PPU & -9.52 & -0.0320 & -1.6667 & 0.9997 & 0.76 & 0.22 & 0.9952 \\
BSU & -5.57 & -0.0446 & -0.8130 & 1.0000 & 0.65 & 0.14 & 0.9903 \\
\hline
\end{tabular}

Key: $R^{2}$ is the correlation coefficient; $q_{\max }$ is the maximum hydrocarbon uptake $(\mathrm{mg} / \mathrm{g}) ; \mathrm{b}$, is Langmuir constant $(\mathrm{L} / \mathrm{mg}) ; K_{f}$, is Freundlich Constant measuring adsorption capacity $(L / m g)$ and $n$, is constant related to adsorption efficiency and energy of adsorption or adsorption intensity of the adsorbent.

Acknowledgement: We would like to acknowledge Dr. (Mrs) Raji and Mr Jude Ejike of the Department of Microbiology, A.B.U, Zaria, who assisted in the microorganisms' isolation and identification. Also, we are grateful to $\mathrm{Mr}$ Oladele Aina for the financial assistance rendered for the success of this work.

\section{REFERENCE}

Abechi, S E; Gimba, C E; Uzairu, A; Dallatu, Y A. (2013). Preparation and characterization of activated carbon from palm kernel shell by chemical activation. Res J Chem. Sci. 3(1): 54-61.

Agarry, S E; Aremu, M O. (2012). Batch and Kinetic Studies of simultaneous Adsorption and Biodegradation of Naphthalene by orange peels immobilized Pseudomonas aeruginosa NCIB 950. J Bioremed Biodegrad 3: 138.

Benchouk, A; Chibani, A. (2017). Petroleumhydrocarbons biodegradation by Pseudomonas strains isolated from hydrocarbon-contaminated soil. Journal of Fundamental and Applied Sciences, 9(2), 713-726.

Chaineau, C H; Rougeux, G; Yepremian, C; Oudot, J. (2005). Effect of nutrient concentration on the biodegradation of crude oil and associated microbial populations in the soil. Soil Biol Biochem 37(8): 1490-1497.

Darsa, K. V; Thatheyus, A J; Ramya, D. (2014). Biodegradation of petroleum compound using the bacterium Bacillus subtilis. Sci Int 2(1): 20-25.

Kadafa, A A. (2012). Environmental impacts of oil exploration and exploitation in the Niger Delta of Nigeria. Glob J Sci Front Res Environ Earth Sci 12 (3): 19-28.
Lin, J; Gan, L; Chen, Z; Naidu, R. (2015). Biodegradation of tetradecane using Acinetobacter venetianus immobilized on bagasse. Biochem Eng J 100: 76-82.

Naga, R M; Ricardo, B; Venkateswartu, K; Andrea, R C; Manjunatha, B. (2016). Removal of petroleum hydrocarbon from crude oil in solid and slurry phase by mixed soil microorganisms isolated from Ecuadorian oil fields. Int Biodeter Biodegr 108: 85-90.

Oladunni, N; Agbaji, E B; Idris, S O. (2012). Removal of $\mathrm{Pb}^{2+}$ and $\mathrm{Ni}^{2+}$ ions from aqueous solutions by adsorption onto activated locust bean (Parkia biglobosa) husk. Arch Appl Sci Res 4 (5): 21612173

Onyegeme-Okerenta, B M; Oharisi, A O; Wegwu, M O. (2017). Impact of crude oil spillage on water and african catfish (clarias gariepinus) in Uzere, Isoko south LGA of Delta State Nigeria. Eur J Earth Environ 4 (1): 2056-5860

Partovinia, A; Naeimpoor, F. (2013). Phenanthrene biodegradation by immobilized microbial consortium in polyvinyl alcohol cryogel beads. Int Biodeterior Biodegr 85: 337-344.

Sreenivasulu, C; Megharaj, M; Venkateswarlu, K; Naidu, R. (2012). Degradation of p-nitrophenol by immobilized cells of Bacillus spp. isolated from soil, Int Biodeter Biodegr 68: 24-27.

Vidal, J. Nigeria's Agony Dwarfs the Gulf Oil Spill. All We Do Is Ignore It, THE GUARDIAN (U.K.), May 30, 2010, at 20:00

Yadav, B K; Hassanizadeh, S M. (2011). An overview of biodegradation of LNAPLs in coastal (semi)arid environment. Water, Air, Soil Pollut 220(14): 225-239. 